\title{
МОГУЋА ИДЕНТИФИКАЦИЈА ХЛЕБНОГ ИДОЛА - ЗАГОНЕТНЕ ПЛОЧИЦЕ СА ЛОКАЛИТЕТА СЕКЕШ КОД ДОРОСЛОВА
}

\author{
Анђелка Путица \\ Градски музеј Сомбор
}

\begin{tabular}{r|r} 
e-mail: anputica@gmail.com & Оригинални научни рад \\
Примљено: 30. 4. 2020. & УДК: 903.26”636”(497.113) \\
Прихваћено: 31. 7. 2020. & $902.2(497.113) ” 2012 "$
\end{tabular}

\begin{abstract}
Апстракт: У раду ће након кратког, општег увода о феномену загонетних плочица - хлебног идола, бити презентован примерак са локалитета Секеш код села Дорослова. По својим основним карактеристикама одступа од уобичајене шеме: кружног је, више дискоидног облика са три урезана знака у облику ияветне крунице. Са територије Србије је до сада познато шест идола у облику векне хлеба, са локалитета: Лепенски Вир (4), Банатска Паланка и Вршаи „Ат”, по један. За идентификацију предмета са локалитета Секеш као идола у облику векне хлеба послужили су фрагметовани примерции који се такође не уклапају у типичне обрасие и форме идола које срећемо на већини локалитета. Загонетне плочице свакако спадају у ред најзанимьивијих налаза из насеља и некропола раног и средњег бронзаног доба. Идентификаџија и презентација намег примерка и његово укључење у мрежу ових загонетних предмета свакако доприноси разумевању повезаности подручја Бачке, а тиме и територије Републике Србије са иентралном и источном Европом.
\end{abstract}

Кључне речи: идоли у облику векне хлеба, хлебни идоли, загонетне плочице, tavolette enigmatiche, Brotlaibidol, плочице са отиском, бронзано доба, Дорослово

Повод за писање рада је налаз предмета са локалитета Секеш код села Дорослова, који припада оној врсти артефаката чију намену није могуће лако утврдити, а какве често срећемо на локалитетима и склони смо да им припишемо загонетна, најчешће ритуална значења. Покушаћемо да кроз анализу и поређење са сличним врстом налаза са других локалитета интерпретирамо и класификујемо дорословачки загонетни предмет као загонетну плочицу са отиском, групу предмета која је током бронзаног доба била средство комуникације, преносилац идеја, те поседовала велику комуникативну моћ повезујући становништво на широком географском подручју, од језера Гарда до Карпата. Функција коју су хлебни идоли или загонетне плочице имали у животу појединца и заједница током бронзаног доба још увек није довољно разјашњена иако се наука тиме бави више од једног века. При- 
ликом тумачења ове врсте артефаката највише пажње се обраћа на облик предмета и украсне мотиве, али поменути елементи и даље не дају одговоре о њиховој функцији и разлогу настанка. Најчешће им се кроз време давало ритуално значење, међутим, како је број пронађених предмета растао, тако се постављају и различите хипотезе о функцији ових предмета. Већина аутора која је проучавала ову проблематику сагласна је са следећим: а) кориштене су као трајна подршка за очување информација, б) биле су познате међу удаљеним и различитим заједницама повезаним само честим комерцијалним контактима и разменама, в) јављају у периоду раног и на почетку средњег бронзаног доба на територији Немачке, Аустрије, Словачке, Чешке, Пољске, Мађарске, Румуније, Хрватске и Србије, али пре свега у области северне Италије, где су и најбројније (David 2011; Carafa 2013; Carafa 2014; Battisti 2015, Ilon 2015; David 2016).

\section{Дефиниција}

Назив загонетна плочица ${ }^{1}$ или хлебни идол користи се да означи археолошке налазе распрострањене широм Европе, чију је функцију тешко дефинисати, а израђени су од глине, ређе од камена, дуги између 3 и 12 цм. Најчешће имају елипсоидни, јајолики и правоугаони облик. Заједничка карактеристика им је присуство знакова на једном или оба лица: геометријски мотиви као што су тачке, кругови, квадрати, правоугаоници, троуглови, жлебови, мотиви крста, ромбови, спирале, понекад испуњени тачкицама или цртама. На једном примерку је отиснут мали спирални наочарасти привезак - карактеристичан украсни предмет у бронзаном добу (Trnka 1982, abb. 4; Mihovilić et al. 2017, 4). У многим случајевима знаци су распоређени преко урезаних водоравних, паралелних линија, али постоје и плочице са знацима распоређеним без очигледног реда. Обично су ознаке утиснуте на свежу глину те овакав начин бележења отисака пре печења указује да су број и организација знакова осмишљени на јединствен начин и представљају трајни запис према јасно утврђеном систему (David 2011, 2; Battisti 2015, 6). Разноликост облика и образаца украса сугерише да се ни у једном случају предмети груписани заједно под колективним називом хлебни идоли или загонетне плочице, у смислу њихове функције, не могу тумачити једнако (David 2016, 27).

\footnotetext{
${ }^{1}$ Како у српској археологији не постоји општеприхваћени термин за овакву врсту налаза, него су се до сада користили преводи углавном са немачког говорног подручја, у даљем тексту биће коришћен термин загонетне плочице (превод са италијанског tavolette enigmatiche), хлебни идоли или плочице са отиском. Порекло речи: Енигма (грч. Ainigma) 1. загонетка, задатак за решавање; 2. Фиг. нејасан, нерешив случај, оно што је загонетно.
} 
Називи су се мењали током времена у складу са епохама, стањем истражености или функционалним интерпретацијама. Њихова функција је најчешће повезивана са магијско-религијском сфером и у том смислу тумачени су као идоли или талисмани у облику плочице (Cornaggia Castiglioni 1976. talismani a tavoletta; Berciu 1953. „idoli”). У употреби су били још и обредни хлеб, пинтадера, глинени идол, идол у облику векне хлеба, рабош, ливачки калуп (Rašajski 1998/99, 15), а поједини аутори задржавају назив Tonstempel, глинени печатњак (Bándi G. 1974, Köninger 1998, Köninger 2006).

На територији Италије најчешћи су у области језера Гарда и називаjу се загонетне плочице или предмети: tavolette enigmatiche односно oggetti enigmatici. ${ }^{2}$ Према италијанским ауторима А. Пиколију и А. Занинију већ сама употреба термина „плочица” подразумева идентификацију предмета са епиграфским значењем (нпр. за бројеве или регистрацију), те они сугеришу да би исправнији назив био tavolette impresse, плочице са отиском (Piccoli and Zanini 1999, 67).

Назив Brotlaibidol везан је за немачко говорно подручје, изведен је од њиховог облика који подсећа на векну хлеба, као што се може видети у компаративном раду Г. Трнке (Trnka 1982), који приказује 32 идола из Аустрије, Швајцарске, Италије, Пољске, Румуније, Словачке и Мађарске. Појам „идоли у облику векне хлеба” у домаћу литературу је увео Р. Рашајски (1988-89), који наглашава да такав назив не сугерише нити морфолошко нити функционално тумачење предмета. На територији Р. Хрватске у скорије време пронађено је 10 предмета са подручја Истре и један из континенталног дела, а приликом интерпретације овог феномена аутори користе термине: крушни идоли, енигматске плочице, плочице са отиском (Mihovilić et al. 2017; Mihovilić 2020).

Н. Тасић наглашава да се тумачење ових загонетних предмета као идола у облику векне хлеба заснива само на форми која подсећа на данашње облике хлеба, те сам термин не треба доводити у везу са њиховом правом функцијом (Tasić 1997, 51).

Ови загонетни предмети обрађени су у богатој стручној литератури неколико пута, при чему су испитани подручје дистрибуције, функција и хронологија (сажети описи Fasani 1970; Bándi; 1974; Trnka 1982; Trnka 1992; Köninger 1998). Стефанија Карафа је дала детаљан попис свих до сада публикованих плочица на територији Европе, уз систематизацију знакова и поделу на седам основних група (Carafa 2013).

\footnotetext{
${ }^{2}$ Шездесетих и седамдесетих година прошлог века открића се множе, нарочито у локалитетима културе Полада на територији северне Италије, те П. Симони први уводи назив „загонетне плочице" - tavolette enigmatiche, који се у италијанској литератури користи до данас (Carafa 2013, 54; Battisti 2015, 4).
} 


\section{Временски и културни оквир}

Загонетне плочице су европски феномен који пратимо на линији од око 1500 км у правцу северозапад-југоисток, од средње Рајне до северозападне Бугарске, током раног и средњег бронзаног доба (2000-1300. године п. н. е.), највише током фазе $\mathrm{BrA}_{2}$ до периода $\mathrm{BrC}_{2}$ (David 2016, 26). Прва загонетна плочица у Словачкој откривена је још 1872 . године, у насељу Мађаровце (Мађарад), а у исто време откривен је и први налаз из области културе Полада југозападно од језера Гарда у Италији (Carafa 2013, 63, 77; David 2016, 26).

Поглед на карту распрострањености ове врсте налаза потврђује мишљење које је дао Рашајски о постојању три основна географска и културна комплекса: карпатска, поладска и подунавска група (Rašajski 1988/89, 15). Са овим се, уз мање промене, слаже већина аутора (Tasić 1997, 51; Şandor Chicideanu, 2002; Carafa 2013, Battisti 2015, 17; David 2016, 26, 27). Број пронађених примерака се од осамдесетих година прошлог века знатно увећао па сада износи преко 300 (Battisti 2015, 4).

Географске групе распростирања идола у облику векне хлеба су:

1. Северна Италија, јужно од језера Гарда, развијена и касна фаза културе

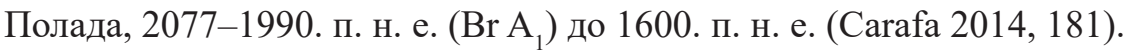

2. Централни Дунав, југозападна Словачка са северозападном Мађарском, Доња и Јужна Моравска у контексту културе Мађаровце: Mad'arovceVěteřov-Böheimkirchen ${ }^{3}$ (класична и посткласична фаза - 1730-1500 п. н. е. Bátora 2000, 510). По мишљењу Г. Бандија трају до краја периода $\mathrm{BrA}_{2}$ и половине $\mathrm{Br}_{1}$, паралелно са завршетком фазе Косидер у дунавском региону, од 1450. до 1350. године п. н. е. (Bándi 1974, 210). Међутим, нови Ц14 датуми за Косидер период дају веома широк распон: од 1870. до 1260. године п. н. е. (Fishl at al.2013, 357, fig. 6, fig. 8; Kiss 2012, 222). ${ }^{4}$ Фаза $\mathrm{Br} \mathrm{C}_{1}-\mathrm{C}_{2}$ у јужној Немачкој око 1450-1400. и 1400-1300. г. п. н. е. одговара фази касног бронзаног доба, односно класичном периоду културе гробних хумки у Мађарској (Fishl at al. 2013, 358).

3. Област Доњег Дунава, Србија, Олтенија, северозападна Бугарска, класична фаза културе Грла Маре - Крна, односно културе инкрустоване керамике Доњег Дунава, датоване у $\mathrm{Br} \mathrm{B}_{1}-\mathrm{C}_{1}$ по централноевропској хронологији, де-

${ }^{3}$ По Герхарду Трнки јављају се у раном бронзаном добу $\left(\mathrm{Br}_{2}-\mathrm{B}_{1}\right)$, повезани са културом Ветеров-Мађаровце (Trnka 1992, 620).

${ }^{4}$ Датуми насељавања касног периода културе гробних хумки почињу око 1400. г. п. н. е. (Ilon 1996). 
лимично се временски поклапају са посткласичном фазом културе Мађаровце између 1600 . и 1400 . п. н. е. $\left(\mathrm{BrB}_{1}\right)$, али се задржавају до $\mathrm{Br}_{1}$ између 1450. и 1350. г. п. н. е. (Şandor Chicideanu 2002).

Бавећи се детаљнијом анализом места настанка и међусобним утицајима између култура, М. Батисти је отишао нешто даље упоређујући локални распоред са временом употребе предмета: прва група плочица (култура Полада) користи се само локално, и то између 2100. и 1850. г. п. н. е., друга група 1850-1650. г. п. н. е. почиње са експанзијом, па су потврђене у трансалпском подручју; одвајају се подгрупе Немачка, Аустрија и Словачка, ${ }^{5}$ од којих се потоња даље шири према западу и Италији, и трећа - између 1650. и 1400. г. п. н. е. - култура Мађаровце врши утицај дуж Дунава до Румуније, док се на италијанском тлу јављају нове подгрупе (Battisti 2015, 17).

\section{Загонетна плочица из Дорослова}

Заштитна археолошка ископавања обављена су на месту изградње брикетаре (фабрика агропелета), на потесу Секеш. ${ }^{6}$ Ископ се налази са десне стране асфалтног пута Дорослово - Српски Милетић, јужно од села Дорослова, на некадашњој обали реке Мостонге. Резултати истраживања омогућили су нам да склопимо прелиминарну хронолошко-стратиграфску слику живота на насељу. Истражен је укупно 201 објекат са покретним материјалом, који је хронолошки опредељен од периода раног бронзаног доба до 16. века (Путица и Узелац 2018). С обзиром на наведени хронолошки оквир у ком се јављају идоли на територији Европе, за овај рад су значајне археолошке јединице из бронзаног доба. Најстарије насеље је везано за рано бронзано доба (Мако култура) са једном стамбеном јединицом, док чак 108 истражених објеката припада периоду средњег и касног бронзаног доба. Богатство покретног археолошког материјала сведочи о преплитању култура (Путица и Узелац 2018, 12-13).

Налази сведоче о бројним привредним и занатским активностима (керамичка производња, обрада метала, коштана индустрија, ткање), различитим гранама пољопривреде, а присуство импозантног фортификационог рова сугерише да је насеље бронзаног доба било трајно и стабилно.

\footnotetext{
${ }^{5}$ Габор Банди први се бавио односом између Поладе и културе Мађаровце, на северу Италије (Bándi 1974).

${ }^{6}$ Покрајински завод за заштиту споменика културе је у сарадњи са Градским музејом Сомбор спровео заштитна археолошка ископавања на траси гасовода у оквиру гасификације општине Сомбор, од априла до децембра 2012. године. Руководилац ископавања био је Драган Анђелић а чланови екипе из Градског музеја Сомбор били су археолози Драган Радојевић и Анђелка Путица.
} 

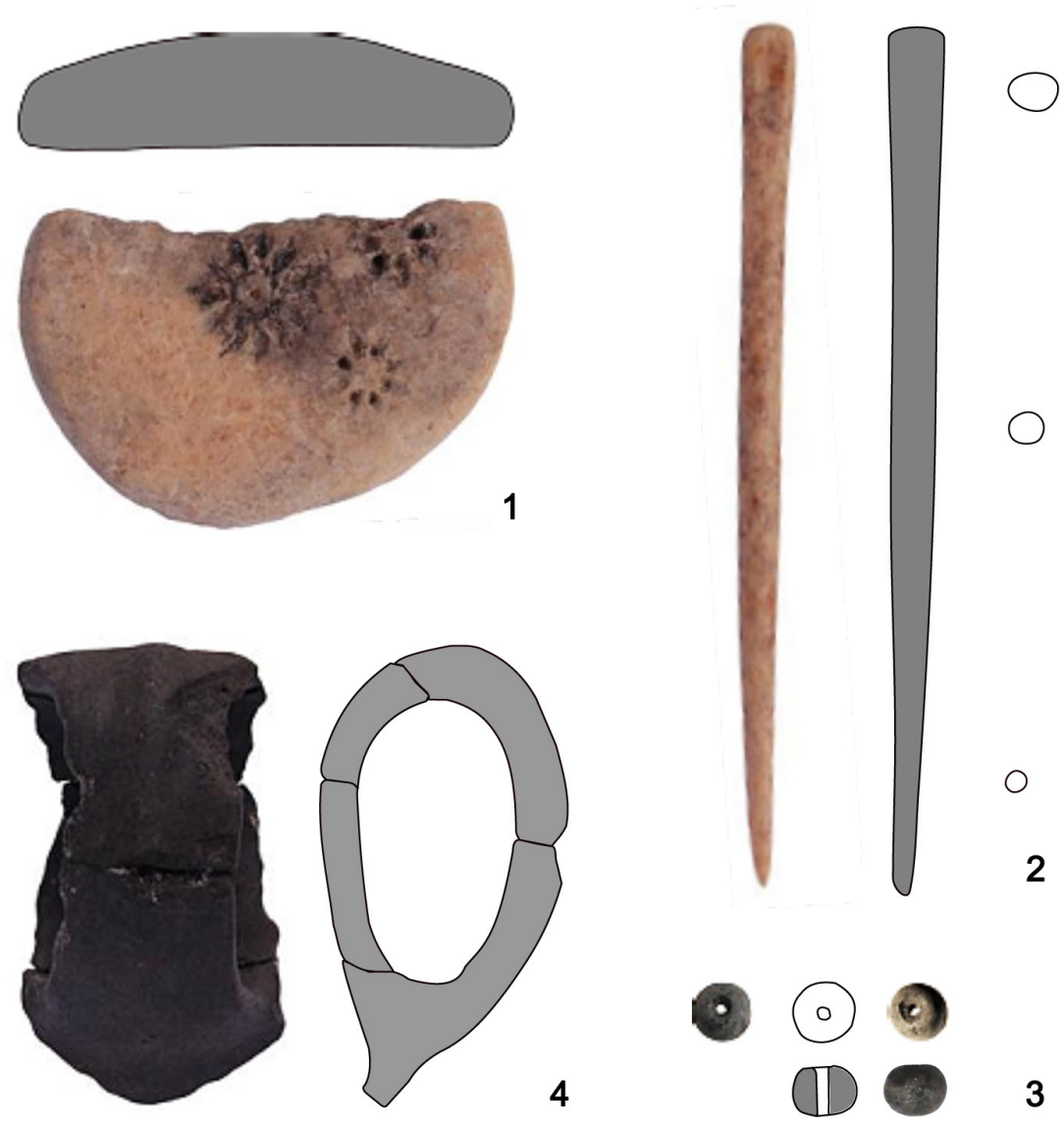

4

3

\section{R 1:1}

Сл. 1. Фрагментовани хлебни идол (1), коштана игла (2), керамичке перле (3), фрагмент шоље са дршком (4), локалитет Секеш, Дорослово

Fig. 1. Fragmented bread loaf idol (1), bone pin (2), ceramic beads (3), fragmented cup with a handle (4); the site of Sekeš, Doroslovo

Насеље на локалитету Секеш је вероватно имало улогу посредника између различитих култура, што се потврђује и открићем могућег „загонетног предмета", који ће бити представљен у овом раду. Фрагментована плочица је дискоидног облика, израђена од светлосмеђе-сиве глине, са равном и нагорелом доњом површином (сл. 1). На горњој, конвексној површини налазе се три знака: круг са тачком у средини, око којег су кружно распоређена зракаста ребра, и два мања круга са зракасто распоређеним ребрима без тачке 


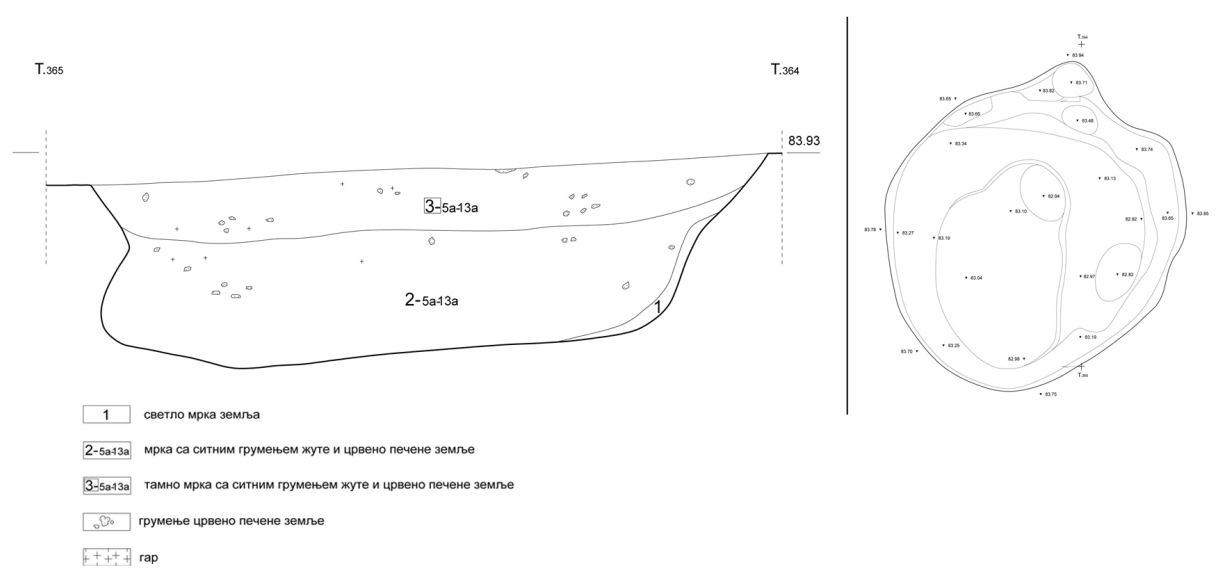

Сл. 2. Објекат 195 (јама), локалитет Секеш, Дорослово

Fig. 2. Feature 195 (pit), the site of Sekeš, Doroslovo

у средини. Пречник: 60 мм; дебљина: 13 мм, инв. бр. 6601. Пронађена је у објекту 195 - јами неправилног облика и неравног дна, димензије објекта: 4,20 х 3,70 м, дубина 0,84 м (сл. 2). У самом објекту ништа не упућује на функцију, а оскудни налази керамике говоре о култури гробних хумки (фрагмент шоље са дршком, ${ }^{7}$ док су остали предмети културно и хронолошки неосетљиви (коштана игла, керамичке перле; слика 1). Фрагмент керамичке шоље са дршком припада носиоцима културе гробних хумки, што свакако није охрабрујући податак за идентификацију нашег предмета као загонетне плочице са отиском, с обзиром на то да постоји мишљење да с појавом ове културе престаје и употреба загонетних плочица (Bándi 1974, 241). Међутим, према недавним подацима, плочице са територије Румуније, па тиме и из читавог региона (трећа група по географској подели), у употреби су до $\mathrm{BrC}_{1}$, између 1450. и 1350. године п. н. е. (Şandor Chicideanu 2002). Резултати АМС анализе из гроба бр. 107 са некрополе Велебит (Kapuran 2018: 40, fig. 8) показују хронолошки оквир између 1407. и 1236. године п. н. е. Док се не ураде анализе материјала са локалитета Секеш (који припада носиоцима културе гробних хумки), а које би показале тачно опредељење, претпостављамо да се временски уклапа са налазима из Велебита.

\footnotetext{
${ }^{7}$ Ово је један од најчешћих облика посуда за пиће касне фазе средњодунавске културе гробних хумки, који се у исто време даље развија у култури поља са урнама. Употреба шиљастих испуста на дршкама троугластог попречног пресека почиње такође у овој млађој фази културе гробних хумки (Ilon 1996, Taf. VIII; Kustár 2000, T.IV/7-10; Mali 2018 , T.8/6-7, T. 9/ 1).
} 
Иако плочица из Дорослова представља изолован случај, покушаћемо да на основу облика знакова на површини пронађемо сличности са доступним примерцима са територија и међу културама бронзаног доба који су били обухваћени овом појавом.

\section{Интерпретација знакова}

Важна прекретница у историји истраживања знакова јесте стварање Европског корпуса загонетних плочица Адалберта Пиколија и Алесандра Занинија. ${ }^{8}$ Знакови су кодирани (компјутерски систем кодирања и упоређивања) у 10 основних типова: тачкасти, једноставни кружни печати, печати са уписаним крстом, троуглови, квадрати, правоугаоници, жлебови, сваки основни знак се јавља у варијантама (Carafa 2013, fig.1, 2). Стефанија Карафа је у својој студији предложила типолошку класификацију плочица на основу основних карактеристика као што су: облици знакова, синтакса, распоред ознака на линијама и морфологије, те су плочице подељене у седам основних група (Carafa 2013).

У неким случајевима фигуративни репертоар одступа од уобичајеног састава знакова (Carafa 2013, 173), као што се и облици појединих плочица разликују до непрепознатљивости од основног обрасца (Rašajski 1989/99, 15). Такве плочице налазимо на територији Италије - Корте Виваро (Corte Vivaro), Немачке - Зинген (Singen), Валхаузен (Wallhausen), и две плочице из Румуније - Дершида (Derşida) (Trnka 1982, 64, abb. 7) и Хрватске, Монкодоња (Mihovilić 2020, s1.2), те примерак са локалитета Алиловци Липље (Mavrović Mokos i Pavličić 2015, sl.18; Mihovilić 2020, sl. 21). Сви наведени примерци су кружног или овалног облика, који се среће веома ретко (Carafa $2013,176)$. Куриозитет представља мотив радијално распоређених линија на површини два примерка из Немачке из Зингена и Валхаузена (Trnka 1982, 64, abb. 6; Carafa 2013, 177). Ове две плочице представљају налаз из насеља раног бронзаног доба $\mathrm{A}_{2} / \mathrm{B}_{1}$ и тумаче се као утицаји Карпатске регије (Trnka $1982,64)$. На плочици из Валхаузена у средини се налази отвор од чијег се центра зракасто шире праве линије делећи круг на десет делова. Облик предмета сугерише на употребу точка у моделима кола која се јављају у средњем Подунављу у контексту културе Мађаровце (Točik, 1964) и култури Полада (Köninger 2006, 256 f.). Кенингер види идола из Валхаузена као резултат контаката са територијом јужне Француске (Köninger, 2006, abb. 2). ${ }^{9}$

\footnotetext{
${ }^{8}$ (Corpus delle Tavolette Enigmatiche europee), ажурирани каталог свих загонетних плочица. www.tavoletteenigmatiche.it

${ }^{9} \mathrm{y}$ средини плочица као што је речено налази се отвор са траговима употребе настао након печења предмета. То би могло бити последица уметања дрвене шипке, која функционише као ротирајућа осовина.
} 
С. Карафа, међутим, примећује да се наведени мотив точка често налази на италијанским плочицама групе 26 (Carafa 2013, 172).

Да бисмо предмет са локалитета Секеш могли да придружимо великој групи загонетних предмета, требало је анализирати како његов облик, тако и мотив на површини. Због тога је истраживање обављено у два смера: облик знака и облик самог предмета који се не уклапа у предложену типолошку класификацију.

Две плочице са локалитета Дершида у Румунији такође су типолошки јединствене, те не постоје генетске везе према другим областима дистрибуције (Trnka 1982, 64, abb. 7). Оба примерка припадају средњем бронзаном добу BrB-C (Trnka 1982, 64). Нетипичним обрасцима припада и примерак са локалитета Алиловци Липље у Пожешкој котлини, пронађен 2009. године у стамбеном објекту датованом на прелазу из раног у средње бронзано доба ${ }^{10}$ (Mavrović-Mokos i Pavličić 2015, 4-7; Mihovilić 2020, 137). На површини плочице овалног облика налази се 14 утиснутих двоструких кругова са радијалним цртицама и дубоким средишњим убодом (Mavrović Mokos i Pavličić 2015, sl. 18). По облику би припадао посебним облицима везаним уз типолошку групу 1 , док је распоред отисака на површини плочице сличан групи 4 по типологији идола Карафа 2013 (Mihovilić 2020, 137, sl. 21).

Управо је облик плочица из Немачке, Румуније и Хрватске послужио за идентификовање предмета са локалитета Секеш као могућег идола у облику векне хлеба. Распоред и облик знакова урезаних на површину плочице из Дорослова такође одступа из познатих образаца. Ради се о три урезана знака у облику цвета, два мања и један већи, неправилног распореда, на очуваном делу горње површине (сл. 4). Сва три знака имају централни круг око којег су радијално распоређени зраци који чине цветну круницу, док највећи има тачку у средини круга. Сличан примерак са три знака на површини неправилног распореда потиче са локалитета Молина ди Ледро (TN; Италија), датован у рано до средње бронзано доба италијанске поделе (Bronzo alto/medio) (Carafa 2013,178, LED 12). ${ }^{11}$ На лицу су урезана три знака која се такође састоје од круга и цветне крунице са тачком у средини. ${ }^{12}$ (сл. 3). Ова врста, односно облик знакова типичан је за прву групу (Carafa

\footnotetext{
${ }^{10}$ Ц14 датуми показали су да припада старијој фази стамбеног објекта у ком је пронађен, 1670-1460. cal BC. (Mavrović-Mokos i Pavličić 2015,7; Mihovilić 2020, 138).

${ }^{11}$ Плочица је такође фрагментована, као и наш примерак, LED 12 плочица Molina di Ledro део је приватне колекције и можда је површински налаз.

12 Знакови Ц5 (круг или чашица са средишњом тачком, зракаста круна и прстенасто распоређене тачке или цртице) и Ц6 (круг или круница са централном тачком и зракастим мотивом).
} 


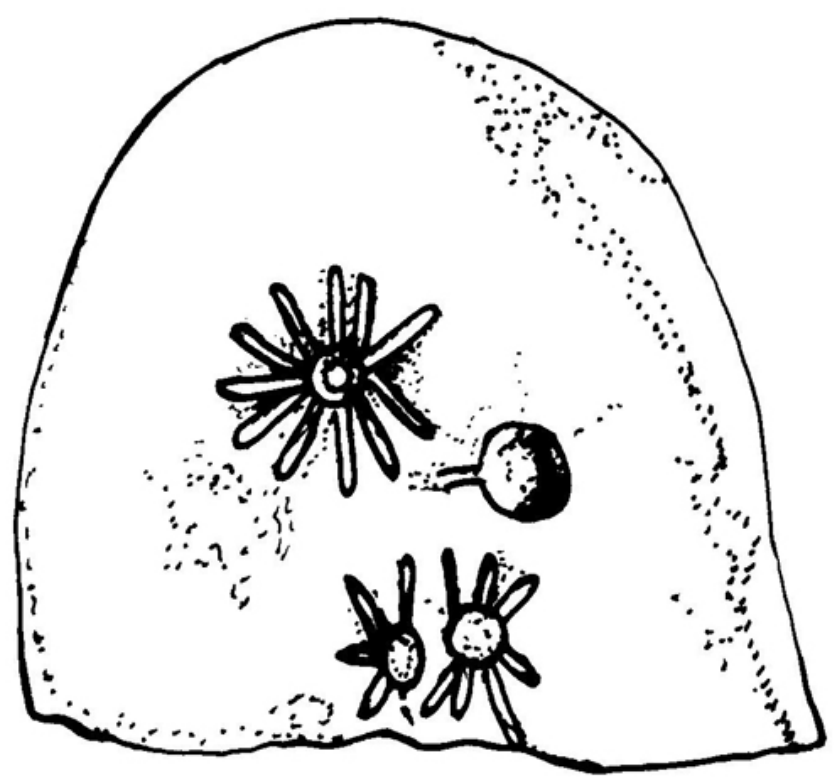

Сл. 3. Фрагментовани идол, Molina di Ledro (TN; Italia), према S. Carafa 2013, LED 12 (цртеж Викторија Узелац)

Fig. 3. Fragmented bread loaf idol from Molina di Ledro (TN; Italia), according to Carafa 2013, LED 12 (drawing by Viktorija Uzelac)

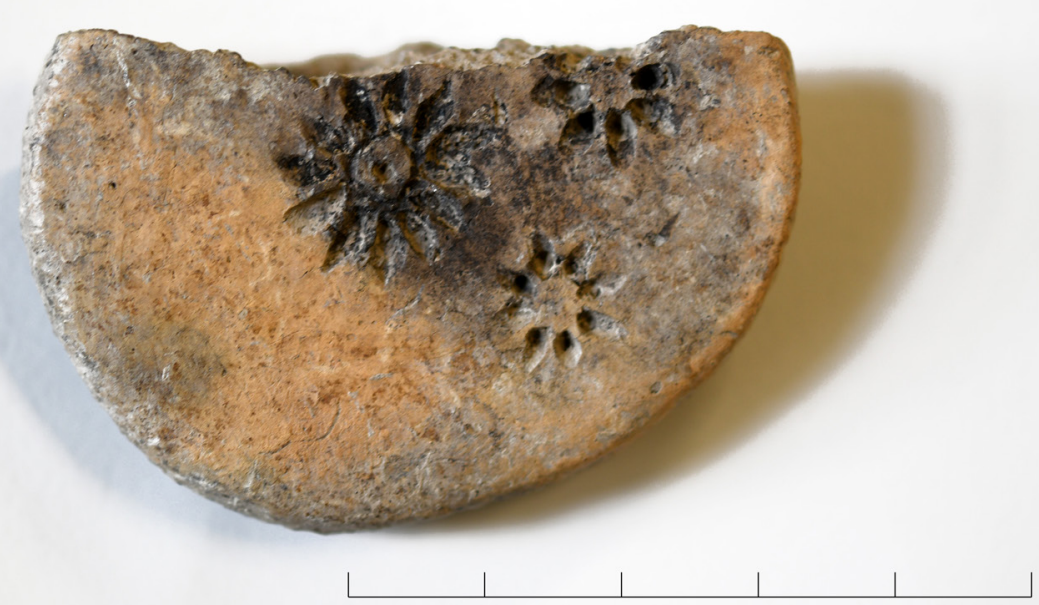

Сл. 4. Хлебни идол, локалитет Секеш (фото Павле Карабасил)

Fig. 4. Bread loaf idol, the site of Sekeš (photo by Pavle Karabasil) 


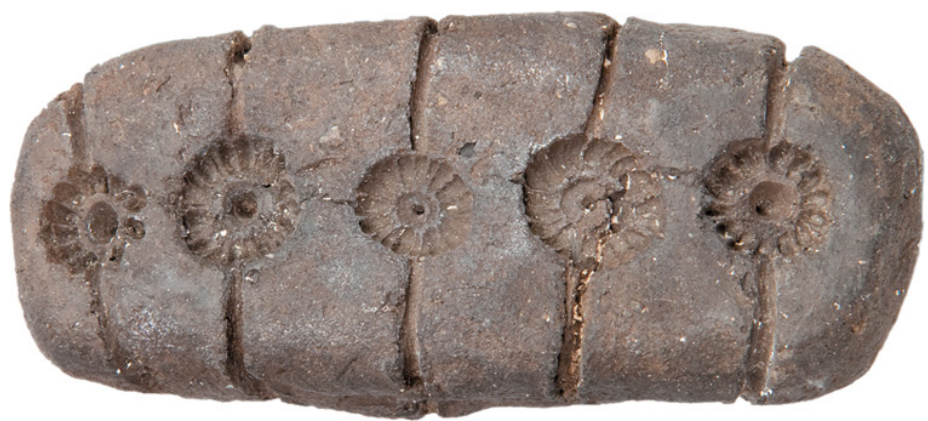

Сл. 5. Хлебни идол, Veselé-Hradisko (Slovačka), prema W. David 2011, abb. 5 Fig. 5. Bread loaf idol, Veselé-Hradisko (Slovakia), according to W. David 2011, abb. 5

2013,173), која је најзаступљенија на локалитетима у Словачкој, Чешкој, те Мађарској равници ${ }^{13}$ (Ilon 2015, 65, 3. kép.; Ilon and Nagy 2013, 301, abb. 2; Bándi 1974, abb. 3, abb. 4/2, 3, 4, 6, abb. 5, abb. 7, abb. 8/5, 6, 8; Vladar 1973, abb. 77/1, 3, 4, 6; Bartik and Bača 1999, obr. 2, obr. 3/1, 3, 4, 20, 21; Carafa 2013, 63, 84-95). За плочице укључене у прву групу, која представља уједно и највећу групу, заједничко је присуство једног знака (сл. 5), који се налази у центру сваког реда: кружница или цветна круница са централном тачком у варијантама (Carafa 2013, 63-95). Највећа концентрација ових плочица је у Словачкој, и то углавном у утврђеном насељу Нитријански Храдок, са којег потичу 24 примерка (Točik 1981; Bándi 1974, abb. 4/1-11, abb. 5/1-2). Поред тога, ова група идола заступљена је и у Аустрији (Trnka 1982, abb. 9, abb. 10/1, abb. 13/4, 6, 8), затим Хрватској (Hänsel et al.1999, fig. 45/8; Teržan et al. 2017, kat. 4, 5; Mihovilić 2020, 122, sl. 6, 7), Румунији (Bándi 1974, abb. 7 , 8; Şandor Chicideanu 2002) и наравно Италији (Carafa 2013, 77-81). Једна од две плочице пронађене у Пољској из Бискупина такође припада овој групи (Carafa 2013, 84).

Када се осврнемо на досад познате идоле са територије Србије и Румуније, који припадају култури Грла Маре - Крна (Gârla Mare-Cîrna) ${ }^{14}$ (Bándi 1974, 239; Rašajski 1988/89, 13-20) средњег бронзаног доба, највећи број њих по облику и украсном мотиву има обележја поменуте 1. групе. Са територије Румуније познато је 13 примерака, а из Србије 6: Банатска Паланка и Вршац „Ат” (Rašajski 1988/89, сл. 1, 2; Tasić 1996, T.V/6), од којих

\footnotetext{
${ }^{13}$ Ménföcsanak, Süttő, Kisterenye, Füzesabony, Tiszafüred (Kovács 1988) и Nagyrozvágy (Koós 2010, 40).

${ }^{14}$ Ову трећу групу идола са Доњег Дунава, по географској подели, Тасић везује за Ватин или раније културе са инкрустованом керамиком у Банату, Серемле или Дубовац тип, односи се на налаз са локалитета Вршац „Ат” (Tasić 1997, 47).
} 
4 са локалитета Лепенски Вир, из приватних колекција (Trnka, 1992). На плочици из Банатске Паланке делимично су очувани трагови црвене боје (Rašajski 1998/99, 17). Ниједан налаз са територије Србије не потиче из археолошки потврђених контекста, него се ради о случајним налазима (Банатска Паланка, Вршац „Ат”), углавном поред некропола Серемле и дубовачкожутобрдске групе (Rašajski 1998/99, 13).

Претпоставља се да је порекло отиска у облику цветне крунице (са централном тачком и зрацима), с обзиром на велику распрострањеност и концентрацију налаза (око 50\%), вероватно територија културе Мађаровце (David 2011, 10; Battisti 2015, 14). Ширење истог мотива на плочицама на подручје Немачке, Румуније и Србије навело је неке ауторе на мишљење да би предмет/инструмент којим су се знаци наносили на влажну површину могао бити од кости или дрвета (Трнка 1992, abb. 1; Bartik and Bača 1999, 20). Apхеоботаничка студија једног од идола са локалитета Veselé-Hradisko ${ }^{15}$ (сл. 5) показала је кроз пресек попречних жлебова да су у питању округли отисци плодова жбунасте биљке (Lavatéra Thuringíaca L.) или неке друге биљке из породице слезова Malvaceae. ${ }^{16}$ (Bartik and Bača 1999, 20, сл. 2/1, 3, сл. 3/ 1, 3; Hajnalova 1999, 27-28; David 2011, Abb. 5). Чињеница да се „округли, зракасти отисци" не јављају на идолима у Италији може се повезати са подручјем настанка ове биљке. Утиснути плодови биљке слеза на загонетним плочицама свакако нису случајност по мишљењу Бартика, јер се мотиви могу наћи на керамичким формама поменутих култура, те аутор претпоставља да је слез вероватно имао посебан значај за човека и заједницу на крају раног и почецима средњег бронзаног доба (Bartik and Bača 1999, 20).

Приликом археометријских анализа је потврђено присуство бакра на површини примерка из Валона (Италија), а највећа концентрација је регистровна у близини знакова, што говори о техници израде - урезивање бакарним шилом (Di Nocera et al. 2015, 118, 119). Претпоставка је да су знаци на плочици из Дорослова такође урезани а не утиснути на влажну глину, што је случај и са примерком из Молине ди Ледро. Према томе, дорословачки идол у облику векне хлеба би као и примерак из Молине ди Ледро припадао групи 7, односно посебним облицима, према С. Карафа (Carafa 2013, 173-178 ), са урезаним мотивом цвета слеза, који је главно обележје 1. групе.

\footnotetext{
${ }^{15}$ Округле, зракасте форме протумачене као отисци плода слеза уочене су на четири примерка идола у облику векне хлеба: два са локалитета Веселе и два са локалитета Нитријански Храдок (Bartik and Bača 1999, 20, obr. 2 / 1-3, obr. 3 / 1, 3.

16 Латински назив Malva Thuringíaca (L.) Српски назив угарски слез, бледоружичаста стола. http://www.biologydiscussion.com/plants/flowering-plants/an-overview-on-malvales-familymalvaceae-botany/19510
} 


\section{Околности налаза и функција загонетних плочица}

Чињеница да многе плочице не долазе из археолошки јасних контекста, него се углавном ради о случајним налазима, отежава одређивање њихове функције. Контекст налаза их дефинише као предмете за свакодневну употребу, јер се ни на једном локалитету не могу директно повезати са култним активностима. Рашајски се, на пример, ослањао на тумачење објеката у ритуалном смислу, међутим, није искључио могућност да су ови артефакти имали различите намене у различитим културама (Rašajski 1989/99, 17, 18). Потичу углавном из насеља, али у централној и источној Европи (Bándi 1974, 237; Trnka 1982, 61; Trnka 1992, 616) постоје примерци са некропола: пример је некропола са спаљеним покојницима Островул Маре Биволари у Румунији (Şandor Chicideanu, 2002). За ове налазе је упитан претпостављени ритуални карактер, јер не постоје јасне индикације које упућују на повезаност са култним радњама. Чак и ако су глинене плочице са некрополе Биволари потицале из гробова, о њиховој повезаности с ритуалним праксама нема аргументоване потврде (Sandor Chicideanu 2002). Једина плочица која долази директно из контекста сахране јесте она са аустријске некрополе Францхаузен (Franzhausen) (Neugebauer and Neugebauer 1997, 175). ${ }^{17}$

На основу података које читамо из околности налаза, оригинална функција ових предмета остаје и даље нејасна, те се поставља питање, ако се не ради о обредним предметима, талисманима, амулетима, да ли они имају посве другачију намену.

Према неким ауторима, плочице су биле повезане са регистрацијом, бележењем ${ }^{18}$ (имовине, добара, занатлија, производа...) и комуникацијом (David 2011, 3, 4; Battisti 2015, 6; David 2016, 27, 28; Palincaş 2012, 25). Начин њихове производње, у ствари, гарантује непроменљивост ознака, а намерно ломљење плочица објашњава се испуњењем сврхе - вид је потврде о неком довршеном, закљученом послу (Mihovilić et al. 2017, 8). Још 1956. године италијански аутор Зорзи је предложио, а с временом је већина аутора прихватила ту тезу, да ове предемете треба посматрати као рачуноводствене документе везане за размену (Carafa 2013, 54). Највећи број пронађених идола потиче из насеља бронзаног доба, у којима се одвијала нека значајна трговинска делатност, а сама насеља била су укључена у велику мрежу

\footnotetext{
${ }^{17}$ Нађена је у гробу 205, са бронзаним шилом на карлици покојника. Постоје индиције да се радило о торби у коју је био смештен овај прибор. Гроб је датован у почетак 18. века п. н. е., а некропола Францхаузен у рано бронзано доба, група Унтервелблинг (Unterwölbling), између 2000. и 1750. године п. н. е. (Carafa 2013, 174).

18 Регистрација, lat. Registratio 1. Уношење, уписивање у регистар, регистарску књигу; 2. Документ као доказ да је спроведено регистровање.
} 
размене добара, знања и искуства (Mihovilić et al. 2017, 8). Као трајна врста документа могли би да упућују на врсту и количину робе која се превози (Battisti 2015, 6), ${ }^{19}$ као нека врста товарног листа или власничке ознаке (David 2016, 28). Могућу везу плочица са трговином ћилибаром ${ }^{20}$ први је предложио Г. Банди (Bándi 1974, 251), док је то мишљење данас упитно. Као разлог наводи се чињеница да је већина европских налаза ћилибара концентрисана у горњим долинама Рајне и Дунава, тј. тамо где су идоли веома ретко документовани. К. Миховилић, напротив, сматра да би се налази могли повезати и са трговачким ћилибарским путем који је водио од Балтика преко подручја реке Зале (Bornhöck), ${ }^{21}$ где је констатован уједно и најсевернији примерак у укопној дистрибуцији плочица са отиском у Европи. Пут би се даље, како предлаже Миховилић, кретао преко западне Мађарске (локалитети Ménföczanak и Vép), у правцу Caput Adriae, према Монкодоњи, док би упитне плочице из Литваније ${ }^{22}$ могле представљати наставак једног од ћилибарских путева уз Балтик или би биле део трговачке руте металним сировинама (Mihovilić 2020, 124, 126, 140). Из подручја културе Грла Маре познат је само један комад ћилибара (Şandor Chicideanu, 2002), а поред тога, нигде нису пронађени комади ћилибара у облику загонетних плочица. Свакако треба споменути налаз перле од ћилибара из насеља Алиловци Липље, уз већ поменути добро очувани примерак загонетне плочице. Перла је датована у 1700. годину п. н. е. и представља једини налаз ћилибара са простора континенталне Хрватске (Mavrović-Mokos i Pavličić 2015, 23, sl.16).

Контакти између заједница на великој удаљености тумаче се присуством истих знакова на плочицама (нетипични, односно некарактеристични за одређену регију). На пример, на плочицама из Монкодоње (Р. Хрватска) јављају се концентрични кругови који су повезани са подручјем северне Италије, док су примерци са попречним урезима и отиском у средини ближи средњоевропском утицају (Mihovilić et al. 2017, 8; Di Nocera et al. 2010, 118).

\footnotetext{
${ }^{19}$ Према овом тумачењу подсећају на месопотамски систем у периоду сумерског протописања, тзв. токене, односно жетоне од глине (прототипови данашњих доставница, транспортних докумената (Battisti 2015, 6)

${ }^{20}$ Идеја о печатима коришћеним у трговини ћилибаром заснива се на сличности идола са печатима из источног медитеранског слива - Египта и микенског подручја, између 15. и 13. века п. н. е. Дистрибуција идола се углавном преклапа са путевима ћилибара или се барем може повезати с њом (Bándi 1974).

${ }^{21}$ Плочица из Борнхука потиче из тумула уњетичке културе, чије се богатство повезује са трговином металима, бакром, цинком, калајем (Mihovilić 2020, 125).

${ }^{22}$ Споран налаз од три плочице за које се сматрало да представљају калупе за ливење накита, пронађене у средњовековном контексту. Једна потиче из женског гроба, уз перле од ћилибара и накит који је чест инвентар у гробовима бронзаног доба (Mihovilić 2020, 140).
} 
Такав је и пример плочице из насеља Физешабоњ-Орегдомб (FüzesabonyOregdomb) у Мађарској, који припада истоименој култури (Kovacs 1988). На плочици се налази серија кружних отисака и припада групи 3 , која се искључиво јавља на територији Италије (Carafa 2013, 136). ${ }^{23}$ Петрографске и минералошке анализе показале су да плочица из Будмерице има исти састав глине као керамички производи пронађени на том локалитету, док је састав глине плочице са локалитета Дворњики-Посадка (Dvorniky-Posádka) потпуно другачији од састава глине који се налази у саставу локалне керамике. Аутори су закључили да је први примерак локалне производње, а да је други увезен, што такође говори о трговинским контактима међу заједницама, те улози и значају загонетних плочица у тим односима (Di Nocera et al. 2015, 118, 119; Bartik and Bača 1999, obr. 3/5).

Најстарије плочице пореклом су са територије културе Полада у северној Италији (Köninger 1998, 457-459), где је и највећа концентрација у укупном броју пронађених предмета - око $45 \%$, те се претпоставља да је на наведеном подручју био успостављен систем циркулације и регистарације имовине. Међусобни трговински контакти територије Поладе са областима у Чешкој и Словачкој које су богате каменоломима и рудницима бакра потврђени су у облицима материјалне културе (Vladar 1973, 322; Battisti 2015, 12). Претпоставља се да се тај утврђени систем контроле превезених производа, успостављен између области Поладе и Словачке, проширио преко Алпа на Аустрију, Немачку а потом и на доњи ток Дунава (Battisti 2015, 8).

Још једна важна заједничка карактеристика насеља у којима су пронађени идоли јесте положај на раскрсници важних речних путева и у подручјима богатим рудом (David 2016, 27; Battisti 2015, 8). Проучавајући идоле у облику векне хлеба са територије Мађарске, Габор Илон је дошао до закључка да је распоред локалитета са којих потичу управо на великим раскрсницама речних путева: долина Мораве, Нитре, Хрона (Гарам), Ипеља, те дуж Рабе (Ilon 2015, 65). Аутор на крају закључује да су сви ови путеви који су постојали миленијумима створили интеракције између различитих културних зајединица које живе у суседним и удаљеним крајевима током раног и средњег бронзаног доба, преко којих објашњава популарност и ширење загонетних плочица (Ilon 2015, 65). Када се сажму налази са територије Xpватске, поред добро познате везе Монкодоње са областима Италије па преко Аустрије ка северу, занимљив је и положај локалитета Алиловци Липље у близини реке Саве. Могуће је да се ради о новом саобраћајном путу у

\footnotetext{
${ }^{23}$ Датована је у период $\mathrm{Br} \mathrm{B} / \mathrm{B} 1$; најстарије плочице групе 3 су из Поладе а представљају и прве објављене налазе са територије Италије (Carafa 2013, 136).
} 
дистрибутивној мрежи плочица који дуж реке Саве повезује територије до ушћа Дунава и обрнуто (Mihovilić 2020, 138).

Поред области северне Италије, југозападна Словачка је други велики центар дистрибуције идола, а издвајају се већ поменута налазишта Веселе-Храдишко и Нитријански Храдок Замечек ${ }^{24}$. Осим тога, ова два насеља су везана за производњу металних предмета и веома развијену металургиjy (Točik 1978). На територији Мађарске једно такво насеље је Нађрозвађ Пап Домб (Nagyrozvágy-Pap Domb), где су у контексту Физешабоњ-Отомани културе нађени калупи за производњу металних предмета (Koós 2010, 40). У насељу је пронађено 6 плочица: 2 од глине и 4 од камена. Локалитет Секеш се налази јужно од села Дорослова, на некадашњој обали реке Мостонге. Њено корито је данас уређено и представља део система Канала Дунав-Тиса-Дунав, те самим положајем који је заузимало (близина Дунава) говори да је било повезано са системом реке Дунав као важном смерницом за културну размену између централне и југоисточне Европе (David 2016, 27). То би била прва карактеристика коју насеље код Дорослова има као заједнички елеменат са поменутим локалитетима у Мађарској, Словачкој и Хрватској. Друга је свакако недавно откриће калупа за производњу накита и оруђа, који непобитно сведоче о неком виду обраде метала и производњи металних предмета у самом насељу (Путица и Јончић 2019). У областима сиромашним рудом, попут Бачке, велика заступљеност металних предмета означава мање или више развијену трговину са околином. Налаз плочице из Дорослова не може се ставити у контекст производње металних предмета, као што то није могуће претпоставити ни на једном локалитету где је потврђена производња металних предмета и налази загонетних плочица. Међутим, подручје њихове дистрибуције подудара се са „путовњем” - међусобним културним контактима и трговином металним предметима и керамиком између различитих заједница током бронзаног доба.

\section{Закључак}

Загонетне плочице су предмети од глине који носе утиснуте или урезане знакове, произведени током бронзаног доба на већини европских територија, као трајна подршка за очување информација међу заједницама које су биле повезане комерцијалним контактима и разменом добара. Један такав предмет са локалитета Секеш покушали смо да на основу аналогија прикључимо овој великој и загонетној групи предмета, па тако и територи-

${ }^{24}$ Са локалитета Нитријански Храдок потичу чак 43 примерка плочица са отиском (Bartik and Bača 1999, 16). 
ју Бачке на систем комуникације који је повезивао удаљене области и био неопходан за одржавање економских и социјалних односа. Циљ овог рада било је и дефинисање врсте и облика могућих контаката које је територија Бачке имала са централном Европом или италијанским полуострвом током средњег бронзаног доба. Докази о загонетној плочици пронађени у овом подручју доприносе и редефинисању географске распрострањености ове врсте налаза, за које се до сада обично веровало да су везани за источне области Србије и културу Жуто брдо.

Можемо закључити да је плочица са локалитета Секеш - иако није препознатљива по систему знакова у предложеној кодификацији - неоспорно могла имати једну од функција, одговарајући на заједничку потребу чак и ако је она још увек нејасна. Препознатљив знак - цветна чашица на дорословачкој плочици са отиском карактеристичним за насеља и културе Карпатског басена, говори о значају и улози самог симбола/знака који се преносио, а то је у овом случају плод слеза.

Гледајући слику распрострањености загонетних плочица у огромном делу древне Европе и анализирајући репертоар утиснутих и урезаних знакова, ограничен на неколико битних облика са њиховим варијацијама, уочава се велика ефикасност овог система комуникације. На основу изнетог претпостављамо да је на загонетним плочицама изражен систем који је вероватно коришћен за комуникацију и регистрацију добара и имовине у већем делу централне и источне Европе и централне и северне Италије током раног и средњег бронзаног доба. Па ипак, ти мали предмети са разноликошћу синтаксе и симбола, које су заједнице бронзаног доба користиле као коิд, били су вероватно употребљени као средство за пренос специфичних информација (Marchesini 2010, 178).

Унутар ове опште слике постоји и низ различитих тумачења њихове улоге, те и могућност да су плочице имале регионални или чак локални карактер. С друге стране, немогуће је искључити међурегионалне контакте, који су документовани на плочици из Дворњики-Посадке, за сада једином импорту, а затим и преко ширења појединих знакова какав је пример плочице из Дорослова. Парадоксално је, како су навели италијански аутори Пиколи и Занини, да је овај врло једноставан облик бележења и комуникације европског бронзаног доба једини изворни елемент наше заједничке прошлости, иако на крајње парцијалан и ограничен начин (Piccoli and Zanini $2015,300)$. Очито су ови предмети играли улогу у трговини на даљину, вероватно и металима. Да ли се ради о некој врсти теретне ознаке или печата као потврде о аутентичности? Да ли су можда чак и кодирани бројеви или друге информације, остаје за сада још увек загонетка. 


\section{БИБЛИОГРАФИЈА}

Bándi, G. 1974. Über den Usprung und die historische Beziehungen der Tonstempel der bronzenzeitlichen Gruppen: Mad'arovče und Polada, Preistoria Alpina 10: 237-252.

Bartík, J., Bača, R. 1999. Bochníkové idoly z Veselého. Príspevok k bochníkovitým idolom z územia Slovenska. Zbornik Slovenského Národného Múzea 93: 13-25.

Battisti, M. 2015. Le tavolette enigmatiche della Vallagarina(Rovereto, TN) nel contesto Europeo, Annali del Museo Civico Rovereto Sezione: Archeologia StoriaScienze Naturali 30 (2014): 3-26

Bátora, J. 2000. Das Gräberfeld von Jelšovce-Slovakei. Ein Beitrag zur Frühbronzezeit im nordwestlichen Karpathenbecken, Prähistorische Archäologie Südosteuropas 16, Oetker/Voges, Kiel.

Berciu, D. 1953. Catalogul muzelui arheologic din Turnu-Severin, Materiale şi Cercetări Arheologice 1: 589-691.

Vladar, J. 1974. Mediterrane Einflusse auf die Kulturentwicklung des nordlichen Karpatenbeckens in der alteren Bronzezeit. Preistoria Alpina 10: 219-236.

Vladar, J. 1973. Osteuropaische und mediterrane Einflusse im Gebiet der Slowakei während der Bronzezeit. Slovenska Archeologia 21/2: 253-357.

David, W. 2011. Aenigma - Der rätselhafte Code der Bronzezeit. „Brotlaibidole” als Medium europäischer Kommunikation vom mehr als 3500 Jahren. Mitteilungen der Freunde der bayerischen Vor- und Frühgeschichte 130: 2-15.

David, W. 2016. Brotlaibidole als Zeugen transalpiner zwischen Südbayern und Norditalien, Bayerische Archäologie 4, 26-30.

Di Nocera, G. M., Rossi, F., Petitti, P., Santamaria, U., Morresi, F. 2015. New data for the understanding of the Vallone enigmatic tablet - Latera Caldera (Valentano, Viterbo, Lazio). In: Tavolette Enigmatiche. Un antico processo di interazione in Europa. Annali Benacensi 15: 113-145.

Ilon, G., 1996. A késő halomsíros-kora urnamezős kultúra temetője és tell települése Németbánya határában (Das Gräberfeld und Tell der Späthügelgräber-Frühurnenfelderkultur in der Gemarkung Németbánya). Pápai Múzeumi Értesítő 6: 89-208.

Ilon, G., Nagy, M. 2013. Brotlaibidole aus Vép (Komitat Vas, Westtransdanubien, Ungarn), Archaeologiai Értesítő 138: 293-303

Ilon, G. 2015. Brotlaibidol („kenyéridol”) Ménfócsanakról / Ein Brotlaibidol aus Ménföcsanak, Ösrégészeti Levelek 14 (2012): 63-69

Kapuran, A. 2018 Jewellery made of bronze sheets from the prehistoric necropolis at the village of Velebit, near Kanjiža, Старинар (н.c.) 68: 33-45.

Carafa, S. 2013. Le tavolette enigmatiche dell'età del Bronzo: proposta di raggruppamento tipologico, tesi di laurea magistrale in Scienze dell'Antichità, Università Ca' Foscari di Venezia, relatore prof. Paolo Biagi, a.a. 2011-2012.

Carafa, S. 2014. Le tavolette enigmatiche: un mistero ancora irrisolto, Bollettino del Centro Camuno di Studi Preistorici: 37-38. 
Kiss, V. 2012. Megjegyzések a magyarországi kora és középső bronzkor relatív és abszolút keltezésének kérdéséhez, M $\Omega \mathrm{MO} \Sigma \mathrm{IV}$ Öskoros Kutatók IV. összejövetelének konferenciakötete : Debrecen, 2005. március 22-24. Debrecen : Déri Múzeum, 215-250

Köninger, J. 1998. Gemusterte Tonobjekte aus der Ufersiedlung Bodman-Schachen I. Zur Verbreitung und Chronologie der sogennannten "Oggetti enigmatici", in Fritsch B., Moute M., Matuschik I., Müller J., Wolf C. (eds.) Tradition und Innovation: 429-468, Rahden Westf., Verlag Marie Leidorf Gmbh.

Köninger, J. 2006. Deckel, Töpfe und gemusterte Tonobjekte. Nachrichtenbl. Arbeitskreis Unterwaserarchäologie 13: 79-82.

Koós, J. 2010. A füzesabonyi kultúra települése Nagyrozvágyon, A Herman Ottó Múzeum évkönyve 49:37-47

Kovács, T. 1988. Die bronzezeitliche Siedlung von Süttő, ein kurze Ubersicht. Slovenska Archeologia 36/1: 119-132.

Kustár, R. 2000. Spätbronzezeitliches Hügelgrab in Isztimér-Csőszpuszta, Alba Regia XXIX: 7-53

Mali, P. 2018. Visegrád-Diós halomsíros időszaki települése, Studia Comitatensia 36: $56-83$

Marchesini, S. 2015. Le Tavolette Enigmatiche: virtù e limiti di un codice, Annali Benacensi XV: 171-181

Mavrović-Mokos, J., i Pavličić, M. 2015. Alilovci, život prije 3700 godina. Katalog izložbe, Požega: Gradski muzej Požega

Mihovilić, K., Hänsel B., Teržan, B. 2017. Brončanodobni krušni idoli, enigmatske pločice ili? tavolette enigmatiche, talismani dell'età del bronzo? Bronze age Loaf-of-Bread Idols, enigmatic Tablets or? Katalog izložbi. Pula: Arheološki muzej Istre

Mihovilić, K. 2020. Krušni idoli - enigmatske pločice - pločice s otiscima iz Monkodonje u: MONKODONJA Istraživanje protourbanog naselja brončanog doba Istre, Knjiga 3, Nalazi od metala, gline, kosti i kamena te ljudskih i životinjskih kostiju, Eds. Biba Teržan, Kristina Mihovilić, 115-146, Monografije i katalozi 34, Pula: Arheološki muzej Istre Neugebauer, C., Neugebauer, J.W. 1997. Franzhausen. Das Frühbronzezeitliche Graberfeld I.Fundeberichte aus Österreich Meterialheft A5. Horn: Berger \& Söhne.

Palincaş, N. 2012.Investigating Bronze Age Social Organisation in the Lower Danube Region, Istros XVIII: 13-38

Piccoli A., Zanini, A. 1999. Le tavolette impresse italiane dell'età del Bronzo. Proposte per una metodologia d'analisi e nuove acquisizioni. Annali Benacensi XII: 63-89.

Piccoli, A., Zanini, A. 2010. Conclusioni, Atti del Congresso Internazionale, TAVOLETTE ENIGMATICHE Un antico processo di interazione in Europa, 16 - 17 - 18 Settembre 2010, Museo Archeologico Cavriana, 297-30

Путица, А., Узелац В. 2018. СоАрхео 2012, резултати заштитних археолошких ископавања на траси гасовода у Општини Сомбор, Сомбор: Градски музеј

Путица, А., Јончић, Н. 2019. Ватра, камен, земља: калупи из бронзаног доба у Градском музеју Сомбор, Зборник Народног музеја (Београд) 24-1: 85-116 
Rašajski, R. 1988-1989. Nalaz „,idola u obliku vekne hleba” kod Banatske Palanke, Pad војвођанских музеја 31: 13-20.

Şandor Chicideanu, M. 2002. Neue Brotlaibidole aus ton dem becken der unteren Donau, in «European Archaeology online», www.archaeology.ro/mcs_brot.htm pristupljeno 14.04.2020.

Tasić, N. 1996. Das Problem der Funde von Szeremle in Banat. The Yugoslav Danube Basin and the neibouring regions in the 2nd milenium B.C. Ed.N. Tasić. Symposium on the occasion of the year of the Bronze age - The first golden age of Europe, October 1114 1995., Vršac, 147-162. Belgrade: Serbian Academy of Sciense and arts and Institut for Balkan Studies

Tasić, N. 1997. Niederösterreich und der jugoslawische Donauraum in der Frü-und Mittelbronzezeit, Relativchronologische Verhältnisse, Старинар н.c. XLVIII: 46-52

Točík, A. 1964. Befestigte bronzezeitliche Ansiedlung in Veselé. Studijné Zvesti 12: 187-291.

Točik, A. 1978. Nitriansky Hrádok-Zameček Bez. Nové Zámky. Bronzezeitliche befestigte Ansiedlung der Mad'arovce Kultur, Materialia Archaeologica Slovaka 3: 1-187

Trnka, G. 1982. "Brotlaibidole in Osterreich. Archaeologia Austriaca 66: 61-80.

Trnka, G. 1992. Neues zu den „Brotlaibidolen“,Universitätsforschungen zur prähistorischen Archäologie 8:615-622.

Fischl, K. P., Kiss, V., Kulcsár, G., and Szeverényi V. 2013. Transformations in the Carpathian Basin around 1600 B.C. in: 1600 - Kultureller Umbruch im Schatten des Thera-Ausbruchs?/16oo - Cultural change in the shadow of the Thera-Eruption? Eds. Harald Meller, François Bertemes, Hans-Rudolf Bork und Roberto Risch,4. Mitteldeutscher Archäologentag vom 14. bis 16.Oktober 2o11 in Halle (Saale), 355-371, Halle:Landesmuseum für vorgeschichte

Hajnalová, E. 1999. Bochníkové idoly s odtlačkami rastlín. Zborník Slovenského Národného Múzea 93-Archeológia 9: 27-28.

Hänsel, B., Mihovilić, K., Teržan, B. 1999. MONKODONJA utvrđeno protourbano naselje starijeg i srednjeg brončanog doba kod Rovinja u Istri, Histria Archaeologica 28/1997: 31-107 


\section{Anđelka Putica}

The Town Museum of Sombor

\section{A POSSIBLE IDENTIFICATION OF A BREAD LOAF IDOL - THE ENIGMATIC TILES FROM THE SITE OF SEKEŠ NEAR DOROSLOVO}

Keywords: Bread loaf idols, bread-like idols, Bronze Age, the site of Sekeš

Objects made of clay, rarely of stone, between 3 and $12 \mathrm{~cm}$ long, most commonly of elliptic shape, with recognizable patterns consisting of different imprints and lines on the surface, are called bread-like or bread loaf idols.

They have been found in Bronze Age settlements from periods between 1850 and 1450 BC across the vast territory of Germany, Austria, Czech Republic, Poland, Croatia, Romania, and Italy, which yielded the largest number of them. It is assumed that bread-like idols were witnesses of sorts of the early European communication network between certain very different cultural groups, among whom were also those from the territory of Serbia. Their common properties include the presence of signs on one or both sides, among which there were some of the favourite geometrical elements from that period (dots, circles, squares, rectangles, triangles), and also motifs of the cross, rhombus, and spirals. In the German-speaking area, they were named "Brotlaibidol" because of their elongated shape, while on the territory of Italy, they are called "enigmatic tiles" or "enigmatic objects" ("tavolette enigmatiche" or "oggetti enigmatici", respectively).

Arrangement and combination of lines and imprints were evidently not accidental or arbitrary and, therefore, there are many different hypotheses about their function. The most common recovery context of bread-like idols defines them as objects for everyday use, because it is rarely that they can be directly associated to cult activities, and there are only two specimens which originate from tombs. Specimens of mid-Danube and Carpathian origin have also been found in settlements in which metallurgical activities were documented.

One such "enigmatic" object was found in Feature 195 (pit) on the site of Sekeš, near Doroslovo. By its basic traits, it deviates from the usual scheme: it has an oval, more discoid shape, with three imprinted motifs (motif of a flower cup). A fragmented example from Molina di Ledro, which also doesn't fit in the typical form of bread idols we encounter on most sites, served as a parallel which enabled the object from the site of Sekeš site to be identified as a bread-like idol. 
The fact that these, essentially uniform objects, are being found in regions distant from one another indicates that tiles have "travelled", covering long distances. In that sense, some scientists have established the hypothesis that bread loaf idols were part of a communication system - as carriers of direct messages or during exchanges of goods. Since the majority of objects is fragmented, we may conclude that they were intentionally broken after being used. 